\title{
Pharmacogenomic considerations for antiplatelet agents: the era of precision medicine in stroke prevention and neurointerventional practice
}

\author{
Phillip A. Bonney, ${ }^{1}$ Benjamin Yim, ${ }^{1}$ Waleed Brinjikji, ${ }^{2}$ and Brian P. Walcott ${ }^{1}$ \\ ${ }^{1}$ Department of Neurological Surgery, University of Southern California, Los Angeles, California 90033, USA; \\ ${ }^{2}$ Departments of Neurosurgery and Radiology, Mayo Clinic, Rochester, Minnesota 55905, USA
}

\begin{abstract}
Antiplatelet drugs are widely utilized in the setting of primary stroke prevention, secondary stroke prevention, and neuroendovascular device-related stroke prevention. These medications are effective in general, although significant variability in drug activity exists between patients. Although this variation may be related in part to a multitude of factors, a growing body of evidence suggests that individual genotypes are a main contributor. The PharmGKB database was mined to prioritize genetic variants with potential clinical relevance for response to aspirin, clopidogrel, prasugrel, and ticagrelor. Although variants were reported for all drugs, the highest level of evidence was found in cytochrome P450 (CYP450) genotype variation related to clopidogrel response. Individual genetic influences have an impact on the pharmacodynamics of antiplatelet agents. Current clinical practice for stroke prevention is primarily empiric or guided by functional assays; however, there now exists a third potential pathway to base treatment decisions: genotype-guided treatment.
\end{abstract}

Corresponding author: bwalcott@usc.edu

(C) 2019 Bonney et al. This article is distributed under the terms of the Creative Commons Attribution-NonCommercial License, which permits reuse and redistribution, except for commercial purposes, provided that the original author and source are credited.

Published by Cold Spring Harbor Laboratory Press

doi:10.1101/mcs.a003731

\section{INTRODUCTION}

Antiplatelet agents are one of the cornerstones of stroke prevention and are widely utilized in the setting of primary stroke prevention, secondary stroke prevention, and neuroendovascular device-related stroke prevention. Their utility is highlighted in several seminal works, which underscore their importance in preventing brain-related ischemia from a diverse array of pathologic processes (Hass et al. 1989; Mohr et al. 2001; Diener et al. 2004; Chimowitz et al. 2005; Markus et al. 2005). Although these drugs are overwhelmingly effective from a population-based standpoint in clinical studies, their efficacy in any single patient may be varied based on a multitude of factors, primarily relating to genotype.

Aspirin (acetylsalicylic acid), the most common antiplatelet drug in use, has a long appreciated resistance phenomenon (Gum et al. 2003; Krasopoulos et al. 2008). With respect to neurovascular disease, patients who experience recurrent ischemia despite adherence to aspirin therapy have been termed aspirin "failures" (Helgason et al. 1993; Bornstein et al. 1994). The addition of a second antiplatelet agent likely increases efficacy, although the mechanism of polytherapy's effect is not always clear. Does an additional agent act synergistically to further decrease already diminished platelet reactivity, or does it simply provide effective antiplatelet activity when an individual is a nonresponder to aspirin? In the latter scenario, continuation of aspirin therapy would provide no benefit while exposing the patient to potential adverse effects, such as gastrointestinal ulcer. 
Clopidogrel, another commonly utilized drug, is well known for exhibiting a resistance phenomenon, which is associated with adverse clinical events (Matetzky et al. 2004; Wang et al. 2005). The prevalence of clopidogrel resistance ranges from $4 \%$ to $44 \%$, depending on the population studied (Gurbel and Tantry 2007). The often essential nature of these medications mandates that an effective antiplatelet response is achieved, as failure could result in substantial morbidity or mortality.

Currently, many patients on dual antiplatelet therapy undergo platelet function testing prior to neurointerventional procedures using a variety of commercially available assays. There are several limitations to many of the currently available platelet function assays, including variability in results across assays, dependence of results on patient hematocrit and platelet counts, and high costs. No high-level evidence exists to support or refute the use of platelet function testing on neurovascular clinical practice. Additionally, the variable clinical practices inspired by the results of these tests have not been well studied.

The ability to better understand the relationship between genotype and drug activity may be able to improve stroke prevention paradigms for neurologists and neurointerventionalists alike. With the ability to perform rapid, accurate, and increasingly lower cost genomic testing, the opportunity to select a specific antiplatelet therapy based on a patient's genotype is approaching clinical practice. The potential benefits of genotype-informed antiplatelet selection include both improved efficacy (stroke prevention) and reduced toxicity (bleeding complications). In this review, we highlight the common and rare genomic variants known to be associated with resistance to drugs most frequently used in clinical practice. From there, we explore future directions of how genomic testing can be integrated into clinical practice to improve stroke prevention.

\section{DATA SYNTHESIS}

Aspirin, clopidogrel, ticagrelor, ticlopidine, and prasugrel were selected for study on the basis of being commonly used in clinical practice. The PharmGKB database (https://www .pharmgkb.org; accessed Oct 22 2018) was mined for variants associated with these drugs. Reports were cross-referenced with original source manuscripts. Annotated variants were then sorted based on levels of evidence as previously described (Whirl-Carrillo et al. 2012). Only the highest quality of annotations (levels 1 and 2) were used for reporting purposes. If high-quality annotations did not exist, then the next two levels of quality were reported. Insufficient genotype data were available to report for ticlopidine. Variants and citations are provided as representative examples and may not represent all information that is available on an allele or be comprehensive of all candidate alleles.

\section{ANTIPLATELET AGENTS}

\section{Aspirin}

Aspirin (acetylsalicylic acid) is an ubiquitous first-generation antiplatelet agent with a long clinical prescribing history. Its primary mechanism of antiplatelet action is attributed to blocking the synthesis of thromboxane A2 from arachidonic acid by irreversible inhibition of prostaglandin G/H synthase 1 (PTGS1, also known as cyclooxygenase 1) within platelets (Vane 1971). Although effective, there are certain individuals resistant to aspirin's effects. In patients with cardiovascular disease, it has been reported that about $5 \%$ of patients are nonresponders to aspirin based on ex vivo testing (Gum et al. 2001, 2003), with up to 23\% considered semiresponders (Gum et al. 2001). Clinically, the most concerning aspect of aspirin resistance is an increased risk of adverse events compared to patients who are aspirin 


\begin{tabular}{|c|c|c|c|c|c|}
\hline References & Level & Population & Gene & $\begin{array}{l}\text { Variant } \\
\text { (GRCh38) }\end{array}$ & Notes \\
\hline $\begin{array}{l}\text { Verschuren et al. 2013; Lepäntalo } \\
\text { et al. } 2006\end{array}$ & $2 b$ & $\begin{array}{l}\text { Acute coronary } \\
\text { syndrome }\end{array}$ & PTGS1 & rs10306114 & $\begin{array}{l}\text { Patients with the AA genotype who are } \\
\text { treated with aspirin may have a decreased, } \\
\text { but not absent, risk for nonresponse to } \\
\text { aspirin as compared to patients with the } \\
\text { AG or GG genotype. }\end{array}$ \\
\hline $\begin{array}{l}\text { Matsubara et al. 2008; Fujiwara } \\
\text { et al. } 2007\end{array}$ & $2 b$ & Healthy volunteer & GP1BA & rs6065 & $\begin{array}{l}\text { Patients with the CC genotype may have an } \\
\text { increased risk for aspirin resistance as } \\
\text { compared to patients with the CT or TT } \\
\text { genotype. }\end{array}$ \\
\hline $\begin{array}{l}\text { Hwang et al. 2011; Marcucci et al. } \\
\text { 2012; Li et al. 2013; Kupstyte } \\
\text { et al. 2015; McDonough et al. } \\
2015\end{array}$ & $2 b$ & $\begin{array}{l}\mathrm{PCl} \text {; acute coronary } \\
\text { syndrome }\end{array}$ & CYP2C19 & rs4244285 & $\begin{array}{l}\text { Patients with the } * 2 / * 2 \text { diplotype may have an } \\
\text { increased incidence of hemorrhage, stroke, } \\
\text { and an overall worse response to } \\
\text { clopidogrel and aspirin, such as decreased } \\
\text { platelet reactivity, as compared to patients } \\
\text { with the } * 1 / * 1, * 1 / * 17, * 17 / * 17, * 1 / * 2 \\
\text { diplotypes. However, this has been } \\
\text { contradicted in some studies. }\end{array}$ \\
\hline
\end{tabular}

(PCI) Percutaneous coronary intervention, (GRCh38) Genome Reference Consortium Human Build 38, (ACS) acute coronary syndrome, (CAD) coronary artery disease. 
Table 2. Clopidogrel_variants

\begin{tabular}{lcccc}
\hline References & Level & Population & Gene & Variant \\
\hline $\begin{array}{l}\text { Wu et al. 2012; Simon et al. } \\
\text { 2009; Mega et al. 2009; }\end{array}$ & 1A & $\begin{array}{c}\text { Acute coronary syndrome; } \\
\text { acute coronary syndrome }\end{array}$ & CYP2C19 & rs4986893 \\
$\begin{array}{l}\text { Wallentin et al. 2010; Lee } \\
\text { et al. 2009 }\end{array}$ & & $\begin{array}{l}\text { undergoing PCl } \\
\text { ind }\end{array}$ & &
\end{tabular}

Anselmi et al. 2013; Sorich et al. 2014; Rideg et al. 2011; Simon et al. 2009; Roberts et al. 2012; Gong et al. 2012

Sun et al. 2015; Verschuren et al. 2013; Hulot et al. 2011; Price et al. 2012

Simon et al. 2009; Mega et al. 2009; Wallentin et al. 2010

Wu et al. 2012; 22028352; Wallentin et al. 2010; Tiroch et al. 2010

\author{
$1 \mathrm{~A}$ Healthy volunteers; acute \\ coronary syndrome; \\ acute coronary syndrome \\ undergoing $\mathrm{PCl} ; \mathrm{PCl}$
}
$1 \mathrm{~A} \mathrm{PCl}$; acute coronary syndrome

1A Acute coronary syndrome

CYP2C19 rs28399504

1A Acute coronary syndrome, $\mathrm{PCl}$
CYP2C19 rs4244285

CYP2C19 Multiple

Patien

\section{Notes}

Patients with the GG genotype (1) may have increased metabolism of clopidogrel and formation of active drug metabolite, resulting in increased response and (2) may have a decreased, but not absent, risk for secondary cardiovascular events when treated with clopidogrel as compared to patients with the AA or $A G$ genotype.

Patients with two functional CYP2C19 alleles $(* 1 / * 1)(1)$ may have increased metabolism of clopidogrel and (2) may have a decreased, but not absent, risk for secondary cardiovascular events when treated with clopidogrel as compared to patients with one or two CYP2C19 loss-of-function alleles (*2 rs4244285, *3 rs4986893, *4 rs28399504, *5 rs56337013, *6 rs72552267, *8 rs41291556).

Patients with the GG genotype (1) may have sufficient metabolism of clopidogrel and increased formation of active drug metabolite and (2) may have a decreased risk for secondary cardiovascular events with clopidogrel as compared to patients with the AA or AG genotype.

Patients with the AA genotype (1) may have increased metabolism of clopidogrel and (2) may have a decreased, but not absent, risk for secondary cardiovascular events when treated with clopidogrel as compared to patients with the $G G$ and $A G$ genotype.

Patients with the CC genotype $(* 1 / * 1)(1)$ may have decreased activation of clopidogrel, (2) may have a decreased, but not absent, risk for bleeding with clopidogrel as compared to patients with the CT or TT genotype, and (3) may have an increased risk for adverse cardiovascular events as compared to patients with a CT or TT genotype. Other genetic, including CYP2C19 lossof-function alleles (e.g.,

*2 rs4244285,*3 rs4986893), and clinical factors may also influence a patient's risk for bleeding and adverse cardiovascular events.

(Continued on next page.) 


\begin{tabular}{|c|c|c|c|c|c|}
\hline References & Level & Population & Gene & $\begin{array}{l}\text { Variant } \\
\text { (GRCh38) }\end{array}$ & Notes \\
\hline $\begin{array}{l}\text { Lewis et al. 2013; Tarkiainen } \\
\text { et al. } 2015\end{array}$ & $2 \mathrm{~B}$ & Healthy volunteer & CES1 & rs71647871 & $\begin{array}{l}\text { Patients with the CC genotype who are } \\
\text { treated with clopidogrel may have } \\
\text { higher on-treatment ADP-induced } \\
\text { platelet aggregation and lower levels of } \\
\text { clopidogrel active metabolite as } \\
\text { compared to patients with the CT or TT } \\
\text { genotype. }\end{array}$ \\
\hline
\end{tabular}

The CPIC recommendations are supported by several notable clinical studies. A subgroup analysis of more than 10,000 patients in the PLATO trial who underwent genotype analysis for various CYP2C19 single-nucleotide polymorphisms found that patients on clopidogrel with loss-of-function CYP2C19 alleles had higher rates of cardiovascular death, myocardial infarction, and stroke at 12 months than those without. In addition, clopidogrel patients with gain of function alleles had higher rates of major bleeding than those without (Wallentin et al. 2010). Recently, implementation of a genotype-driven prediction model for clopidogrel resistance was shown to reduce cardiovascular events in patients undergoing PCl by nearly threefold (Cavallari et al. 2018). In addition, data that correlate results of functional assays with clinical outcome, demonstrating the association between decreased platelet inhibition and clinical events, has been published (Matetzky et al. 2004). Large-scale efforts are underway to identify additional determinants of patient response to clopidogrel by cross-referencing genetic and platelet function data (Bergmeijer et al. 2018).

Clopidogrel, perhaps more so than any other drug, has several known nongenetic factors that influence response in any one individual, making interpretation of genetic variation challenging. Several prevalent conditions including diabetes mellitus and renal impairment are associated with blunted responses to clopidogrel (Geisler et al. 2007; Best et al. 2008; Park et al. 2009). Additionally, several common medications including proton pump inhibitors appear to reduce the antiplatelet effects of clopidogrel through competition for shared metabolic pathways (CYP2C19) in the liver (Gilard et al. 2006, 2008; Ho et al. 2009).

\section{Prasugrel (Effient)}

Prasugrel is a next-generation antiplatelet agent that inhibits ADP-platelet activation by irreversibly binding to the P2Y12 receptor. Like clopidogrel, the ingested form of the drug needs to be converted to an active metabolite. This occurs both by CYP450-dependent conversion and by carboxylesterase 2-mediated hydrolysis during absorption (Huber et al. 2009; Mega et al. 2009; Farid et al. 2010). In contrast to clopidogrel, prasugrel tends to have a more efficient absorption and is more rapidly converted to its active metabolite. Furthermore, although CYP450 genetic variants exist, many do not have a functional consequence on prasugrel activity (Brandt et al. 2007; Mega et al. 2009, 2010; Varenhorst et al. 2009). There are isolated reports of prasugrel resistance (Alexopoulos 2012; Fiore et al. 2014), and preliminary research suggests that polymorphisms in PEAR1 may contribute to variation in pharmacodynamics response (see Table 3; Xiang et al. 2013; Fisch et al. 2015).

Despite the potential advantage of averting resistance phenomenon seen with clopidogrel, the largest randomized trial of prasugrel versus clopidogrel (performed in patients with coronary disease) demonstrates conflicting evidence regarding increased hemorrhagic complications between different subgroups of patients (Wiviott et al. 2007; Montalescot et al. 2009). 


\begin{tabular}{|c|c|c|c|c|c|}
\hline Reference(s) & Level & Population & Gene & $\begin{array}{l}\text { Variant } \\
\text { (GRCh38) }\end{array}$ & Notes \\
\hline Xiang et al. 2013 & 3 & Healthy volunteer & PEAR1 & rs822441 & $\begin{array}{l}\text { Patients with the CC genotype who are treated with } \\
\text { prasugrel may have lower levels of platelet } \\
\text { aggregation inhibition as compared to patients with } \\
\text { the CG or GG genotype. }\end{array}$ \\
\hline Xiang et al. 2013 & 3 & Healthy volunteer & PEAR1 & rs12407843 & $\begin{array}{l}\text { Patients with the AA genotype who are treated with } \\
\text { prasugrel may have lower levels of platelet } \\
\text { aggregation inhibition as compared to patients with } \\
\text { the } A G \text { or } G G \text { genotype. }\end{array}$ \\
\hline Xiang et al. 2013 & 3 & Healthy volunteer & PEAR1 & rs77235035 & $\begin{array}{l}\text { Patients with the AA genotype who are treated with } \\
\text { prasugrel may have lower levels of platelet } \\
\text { aggregation inhibition as compared to patients with } \\
\text { the AC or CC genotype. }\end{array}$ \\
\hline Cuisset et al. 2012 & 3 & $\begin{array}{l}\text { Acute coronary syndrome } \\
\text { treated with } \mathrm{PCl}\end{array}$ & CYP2C19 & rs12248560 & $\begin{array}{l}\text { Patients with the TT and CT genotype and acute } \\
\text { coronary syndrome who are treated with prasugrel } \\
\text { may have an increased risk for bleeding as } \\
\text { compared to patients with the CC genotype. }\end{array}$ \\
\hline Xiang et al. 2013 & 3 & Healthy volunteer & PEAR1 & rs3737224 & $\begin{array}{l}\text { Patients with the TT genotype who are treated with } \\
\text { prasugrel may have lower levels of platelet } \\
\text { aggregation inhibition as compared to patients with } \\
\text { the CT or CC genotype. }\end{array}$ \\
\hline Xiang et al. 2013 & 3 & Healthy volunteer & PEAR1 & rs822442 & $\begin{array}{l}\text { Patients with the } \mathrm{CC} \text { or } \mathrm{AC} \text { genotype who are treated } \\
\text { with prasugrel may have higher levels of platelet } \\
\text { aggregation inhibition as compared to patients with } \\
\text { the AA genotype. }\end{array}$ \\
\hline Xiang et al. 2013 & 3 & Healthy volunteer & PEAR1 & rs41273215 & $\begin{array}{l}\text { Patients with the TT genotype who are treated with } \\
\text { prasugrel may have lower levels of platelet } \\
\text { aggregation inhibition as compared to patients with } \\
\text { the CT or CC genotype. }\end{array}$ \\
\hline $\begin{array}{l}\text { Cuisset et al. } \\
\text { 2012; Brandt } \\
\text { et al. } 2007\end{array}$ & 3 & $\begin{array}{l}\text { Acute coronary syndrome } \\
\text { treated with } \mathrm{PCl} ; \\
\text { healthy individuals }\end{array}$ & CYP2C19 & rs4244285 & $\begin{array}{l}\text { Patients with the GG genotype who are treated with } \\
\text { prasugrel may have a lower rate of high on- } \\
\text { treatment platelet reactivity at } 1 \text { mo of treatment as } \\
\text { compared to patients with the AG or AA genotype. } \\
\text { However, contradictory findings are reported. }\end{array}$ \\
\hline
\end{tabular}

This trial also demonstrated the feasibility of investigating the genetic underpinnings of platelet functionality and clinical outcome (Mega et al. 2010). Comparison of these drugs for the treatment of patients with neurovascular disease has not been performed, and widespread adoption of prasugrel has not occurred.

\section{Ticagrelor (Brilinta)}

Ticagrelor is another next-generation antiplatelet agent. Uniquely, the drug does not require in vivo bioactivation in order to reversibly inhibit the P2Y12 receptor (Schömig 2009). Still, it undergoes metabolism via CYPP450 3A4 and 3A5 metabolism to generate an equipotent metabolite, AR-C124910XX (Teng et al. 2010; Giorgi et al. 2011). Ticagrelor has been studied extensively in the cardiovascular literature, and a randomized trial (PLATO) with subgroup analysis of genetic polymorphisms concluded that it is more efficacious at preventing cardiovascular death, myocardial infarction, or stroke than clopidogrel, irrespective of genetic makeup (Wallentin et al. 2010). Enthusiasm for the drug in stroke prevention in particular was tempered by a head-to-head randomized trial of aspirin and ticagrelor, 


\begin{tabular}{|c|c|c|c|c|c|}
\hline Reference & Level & Population & Gene & $\begin{array}{l}\text { Variant } \\
\text { (GRCh38) }\end{array}$ & Notes \\
\hline $\begin{array}{l}\text { Varenhorst } \\
\text { et al. } 2015\end{array}$ & 3 & $\begin{array}{l}\text { Acute coronary } \\
\text { syndrome }\end{array}$ & SLCO1B1 & rs113681054 & $\begin{array}{l}\text { Patients with the TT genotype and acute coronary syndrome may } \\
\text { have decreased concentrations of ticagrelor compared to } \\
\text { patients with the CC and CT genotypes. }\end{array}$ \\
\hline $\begin{array}{l}\text { Varenhorst } \\
\text { et al. } 2015\end{array}$ & 3 & $\begin{array}{l}\text { Acute coronary } \\
\text { syndrome }\end{array}$ & CYP3A43 & rs62471956 & $\begin{array}{l}\text { Patients with the GG genotype and acute coronary syndrome may } \\
\text { have decreased concentrations of ticagrelor compared to } \\
\text { patients with the AA or AG genotypes. }\end{array}$ \\
\hline $\begin{array}{l}\text { Varenhorst } \\
\text { et al. } 2015\end{array}$ & 3 & $\begin{array}{l}\text { Acute coronary } \\
\text { syndrome }\end{array}$ & UGT2B7 & rs61361928 & $\begin{array}{l}\text { Patients with the TT genotype and acute coronary syndrome may } \\
\text { have decreased concentrations of ticagrelor compared to } \\
\text { patients with the CT genotype. }\end{array}$ \\
\hline $\begin{array}{l}\text { Varenhorst } \\
\text { et al. } 2015\end{array}$ & 3 & $\begin{array}{l}\text { Acute coronary } \\
\text { syndrome }\end{array}$ & SLCO1B1 & rs4149056 & $\begin{array}{l}\text { Patients with the TT genotype and acute coronary syndrome may } \\
\text { have decreased concentrations of ticagrelor compared to } \\
\text { patients with the CC and CT genotypes. }\end{array}$ \\
\hline $\begin{array}{l}\text { Varenhorst } \\
\text { et al. } 2015\end{array}$ & 3 & $\begin{array}{l}\text { Acute coronary } \\
\text { syndrome }\end{array}$ & CYP3A4 & rs56324128 & $\begin{array}{l}\text { Patients with the CT genotype and acute coronary syndrome may } \\
\text { have increased concentrations of ticagrelor compared to } \\
\text { patients with the TT genotype. }\end{array}$ \\
\hline Li et al. 2017 & 4 & $\begin{array}{l}\text { Healthy } \\
\text { volunteer }\end{array}$ & PEAR1 & rs12041331 & $\begin{array}{l}\text { Patients with the GG genotype may have deceased inhibition of } \\
\text { platelet aggregation in response to ticagrelor compared to } \\
\text { patients with the AA genotype. }\end{array}$ \\
\hline Li et al. 2017 & 4 & $\begin{array}{l}\text { Healthy } \\
\text { volunteer }\end{array}$ & PEAR1 & rs12566888 & $\begin{array}{l}\text { Patients with the TT genotype may have lower maximal platelet } \\
\text { aggregation than patients with the GT genotype when taking } \\
\text { ticagrelor. }\end{array}$ \\
\hline Li et al. 2017 & 4 & $\begin{array}{l}\text { Healthy } \\
\text { volunteer }\end{array}$ & PEAR1 & rs4661012 & $\begin{array}{l}\text { Patients with the TT genotype may have decreased inhibition of } \\
\text { platelet aggregation when taking ticagrelor compared to } \\
\text { patients with the GG genotype. }\end{array}$ \\
\hline
\end{tabular}

yielding no difference in the rate of stroke, myocardial infarction, or death in the follow-up period after stroke or transient ischemic attack (Johnston et al. 2016).

The influence of genetic polymorphisms on ticagrelor activity is not well studied. A genome-wide association study of the patients with acute coronary syndrome in the above-mentioned PLATO study revealed three loci (SLCO1B1, UGT2B7, and CYP3A4) that potentially influence its pharmacokinetics to a modest degree (Varenhorst et al. 2015). In this limited study, no difference in efficacy or safety was observed based on the variation in ticagrelor levels, leading the authors to conclude that use of ticagrelor does not require genetic testing. Other preliminary studies have identified loci potentially affecting drug levels or activity, with unclear clinical significance (see Table 4).

\section{DISCUSSION}

Individual genetic influences have an impact on the pharmacokinetics and pharmacodynamics of antiplatelet agents. Although clopidogrel is one of the most variable in terms of individual response, it remains one of the most frequently prescribed medications for secondary stroke prevention and device-related stroke prevention. Given the limitations of clopidogrel, there is shifting precedence in the cardiology literature from using clopidogrel to using either prasugrel or ticagrelor along with aspirin for dual antiplatelet therapy. A recent joint guideline from the American College of Cardiology/American Heart Association (Level of Evidence $B$ recommendation) states it is "reasonable to use prasugrel or ticagrelor in preference to clopidogrel" for most patients with acute coronary syndromes treated with or 
without stenting (Levine et al. 2016). Along these lines, the rate of prescribing either prasugrel or ticagrelor is approaching the rate of prescribing clopidogrel for these patients (Dayoub et al. 2018). Similar use of next-generation antiplatelet agents has not yet occurred for stroke prevention. With the consequences of antiplatelet therapy being so profound in neurological disease-both beneficial and potentially harmful-further consideration should be given to investigating the potential of individualized regimens.

Several recent transformational advances in medicine have occurred to facilitate the potential for individualized pharmacologic stroke prevention. In terms of discovery potential, the ability to perform high-throughput, large-scale sequencing in a large population is now a reality. In a study of more than 50,000 patients, whole-exome sequencing was performed and correlated with phenotypes extracted from the clinical medical record to discover novel disease-associated variants (Dewey et al. 2016). For neurovascular patients, this powerful technique has the potential to survey the entire genomic landscape in an unbiased fashion. Exome sequencing has been applied in limited fashion to identify novel variants associated with platelet reactivity to clopidogrel, an approach that may be fruitful in larger studies (Scott et al. 2016; Lewis and Shuldiner 2017). This is an attractive approach, linking genetic data with platelet function assays and clinical outcomes to study a population comprehensively, forgoing the need to make a priori inferences about clinical significance.

Beyond discovery, genomic characterization is also poised to transform therapeutic decision-making for neurovascular patients. In a proof-of-principle study, investigators randomized patients to genotype-based or clinically based (typical) dosing of warfarin to prevent venous thromboembolism after orthopedic surgery (Gage et al. 2017). Because warfarin has variation in bioactivity secondary to different genotypes, similar to antiplatelet agents like clopidogrel, it was hypothesized that genotype-based dosing would optimize treatment within the therapeutic index. Indeed, the genotype-based dosing group experienced a lower combined risk of bleeding, international normalized ratio of 4 or greater, venous thromboembolism, or death. This idea was recently replicated for clopidogrel in cardiovascular disease, in which patients were treated with prasugrel or ticagrelor in the event of pharmacogenetic evidence of clopidogrel resistance (Cavallari et al. 2018). Patients with predicted clopidogrel resistance, assessed by CYP2C19 genotyping for loss-of-function alleles, who were treated with an alternative antiplatelet agent experienced adverse thrombotic events at a lesser rate than those treated with clopidogrel and at a similar rate to those without clopidogrel resistance who were treated with clopidogrel. In similar fashion, could genotypebased antiplatelet selection improve the safety and efficacy of treatment in neurovascular patients? Further study is needed (Table 5).

Certain challenges arise when translating genetic discovery to clinical practice for stroke prevention. For one, robust genotype-phenotype associations do not yet exist with regard to genotype and response to antiplatelet therapy in this specific population. Given the widespread use of platelet function assays (albeit inconsistent in frequency and with different techniques) and the availability to perform follow-up surveillance neuroimaging, clinical data can be collected to bridge the understanding between genetic variation and clinical outcomes. Additionally, the umbrella of neurovascular disease encompasses a heterogeneous group of pathophysiology, from cervical carotid artery stenosis to flow-diverting stents for giant aneurysms, and identifying patients at similar risk/mechanism for thrombosis is essential.

Competing Interest Statement

The authors have declared no competing interest.

\section{Referees}

Wenndy Hernandez Anonymous
Although current clinical practice for stroke prevention is primarily empiric antiplatelet therapy with aspirin and/or clopidogrel, a large proportion of the population with genetic variation resulting in varied drug bioactivity exists. Whether this variation stems from genetic ancestry or otherwise (Johnson et al. 2017), genotyping is essential for a better understanding. For patients undergoing interventional procedures, ex vivo platelet function assays used to tailor dosing regimens to meet arbitrary therapeutic windows is fraught with individual experimentation. In addition to purely empiric treatment and functional assay-guided 
Table 5. Ongoing clinical trials investigating pharmacogenomics in antiplatelet use

\begin{tabular}{|c|c|c|c|c|}
\hline $\begin{array}{l}\text { Clinicaltrials } \\
\text { gov ID }\end{array}$ & Study title (Location) & $\begin{array}{l}\text { Estimated year } \\
\text { of completion }\end{array}$ & Enrollment & Summary \\
\hline NCT02955121 & $\begin{array}{l}\text { IU Health Krannert Personalized Medicine } \\
\text { Study }\end{array}$ & 2018 & 270 & $\begin{array}{l}\text { Patients undergoing } \mathrm{PCl} \text { randomized to } \\
\text { receive genotyping for CYP2C19 LOF } \\
\text { alleles versus no genotyping. Use of } \\
\text { genotyping to guide antiplatelet use is } \\
\text { optional. }\end{array}$ \\
\hline NCT01930773 & $\begin{array}{l}\text { Bedside Genetic or Pharmacodynamic } \\
\text { Testing to Prevent Periprocedural } \\
\text { Myonecrosis During PCI (ONSIDE TEST, } \\
\text { Hungary/Poland) }\end{array}$ & 2018 & 150 & $\begin{array}{l}\text { Patients undergoing PCI randomized to } \\
\text { genotype-based (CYP2C19 LOF alleles) } \\
\text { versus phenotype-based (platelet } \\
\text { function assay) determination of } \\
\text { clopidogrel resistance for treatment with } \\
\text { prasugrel. }\end{array}$ \\
\hline NCT01641510 & $\begin{array}{l}\text { PRAsugrel or clopldogrel In Acute Coronary } \\
\text { SyndromE With CYP2C19 GENEtic } \\
\text { Variants (Korea) }\end{array}$ & 2018 & 70 & $\begin{array}{l}\text { Patients with ACS and CYP2C19 LOF alleles } \\
\text { randomized to high loading dose + } \\
\text { standard maintenance dose clopidogrel } \\
\text { versus half-dose prasugrel. }\end{array}$ \\
\hline NCT01761786 & $\begin{array}{l}\text { Cost-effectiveness of Genotype-Guided } \\
\text { Treatment With Antiplatelet Drugs in } \\
\text { STEMI Patients: Optimization of Treatment } \\
\text { (POPular Genetics; multiple European } \\
\text { sites) }\end{array}$ & 2019 & 2700 & $\begin{array}{l}\text { Patients undergoing } \mathrm{PCl} \text { randomized to } \\
\text { receive genotyping for CYP2C19 LOF } \\
\text { alleles versus no genotyping. Patients in } \\
\text { genotyping arm receive prasugrel/ } \\
\text { ticagrelor if LOF CYP2C19 alleles, } \\
\text { otherwise clopidogrel. Patients in control } \\
\text { arm receive prasugrel/ticagrelor. }\end{array}$ \\
\hline NCT02724319 & $\begin{array}{l}\text { Implementation of CYP2C19 Genotyping to } \\
\text { Guide Antiplatelet Therapy (Florida) }\end{array}$ & 2019 & 2500 & $\begin{array}{l}\text { Patients undergoing cardiac catheterization } \\
\text { receive buccal swab genotyping for } \\
\text { CYP2C19 LOF alleles with optional } \\
\text { genotype-guided therapy for patients } \\
\text { receiving PCl. }\end{array}$ \\
\hline NCT02065479 & $\begin{array}{l}\text { A Pharmacodynamic Study Comparing } \\
\text { Prasugrel Versus Ticagrelor in Patients } \\
\text { Undergoing PCI With CYP2C19 Loss-of- } \\
\text { function (Florida) }\end{array}$ & 2019 & 100 & $\begin{array}{l}\text { Patients undergoing } \mathrm{PCl} \text { with CYP2C19 LOF } \\
\text { alleles randomized to receive prasugrel } \\
\text { versus ticagrelor. }\end{array}$ \\
\hline NCT03489863 & $\begin{array}{l}\text { Prasugrel Versus Ticagrelor in Patients With } \\
\text { CYP2C19 Loss-of-function: a Validation } \\
\text { Study (Florida) }\end{array}$ & 2019 & 50 & $\begin{array}{l}\text { Patients with CAD not undergoing } \mathrm{PCl} \text { with } \\
\text { CYP2C19 LOF alleles randomized to } \\
\text { receive prasugrel versus ticagrelor. }\end{array}$ \\
\hline
\end{tabular}

treatment, a third potential pathway to base treatment decisions is now available: genotypeguided treatment.

\section{REFERENCES}

Alexopoulos D. 2012. Prasugrel resistance: fact or fiction. Platelets 23: 83-90. doi:10.3109/09537104.2011 .600478

Anselmi CV, Briguori C, Roncarati R, Papa L, Visconti G, Focaccio A, De Micco F, Latronico MV, Pagnotta P, Condorelli G. 2013. Routine assessment of on-clopidogrel platelet reactivity and gene polymorphisms in predicting clinical outcome following drug-eluting stent implantation in patients with stable coronary artery disease. JACC Cardiovasc Interv 6: 1166-1175. doi:10.1016/j.jcin.2013.06.010

Bergmeijer TO, Reny J-L, Pakyz RE, Gong L, Lewis JP, Kim E-Y, Aradi D, Fernandez-Cadenas I, Horenstein RB, Lee MTM, et al. 2018. Genome-wide and candidate gene approaches of clopidogrel efficacy using pharmacodynamic and clinical end points-Rationale and design of the International Clopidogrel Pharmacogenomics Consortium (ICPC). Am Heart J 198: 152-159. doi:10.1016/j.ahj.2017.12.010 
Best PJ, Steinhubl SR, Berger PB, Dasgupta A, Brennan DM, Szczech LA, Califf RM, Topol EJ, CREDO Investigators. 2008. The efficacy and safety of short-and long-term dual antiplatelet therapy in patients with mild or moderate chronic kidney disease: results from the Clopidogrel for the Reduction of Events During Observation (CREDO) trial. Am Heart J 155: 687-693. doi:10.1016/j.ahj.2007.10.046

Bornstein NM, Karepov VG, Aronovich BD, Gorbulev AY, Treves TA, Korczyn AD. 1994. Failure of aspirin treatment after stroke. Stroke 25: 275-277. doi:10.1161/01.STR.25.2.275

Brandt J, Close S, Iturria S, Payne C, Farid N, Ernest C, Lachno D, Salazar D, Winters K. 2007. Common polymorphisms of CYP2C19 and CYP2C9 affect the pharmacokinetic and pharmacodynamic response to clopidogrel but not prasugrel. J Thromb Haemost 5: 2429-2436. doi:10.1111/j.1538-7836.2007.02775.x

Cavallari LH, Lee CR, Beitelshees AL, Cooper-DeHoff RM, Duarte JD, Voora D, Kimmel SE, McDonough CW, Gong Y, Dave CV, et al. 2018. Multisite investigation of outcomes with implementation of CYP2C19 genotype-guided antiplatelet therapy after percutaneous coronary intervention. JACC Cardiovasc Interv 11: 181-191. doi:10.1016/j.jcin.2017.07.022

Chen W-H, Cheng X, Lee P-Y, Ng W, Kwok JY-Y, Tse H-F, Lau C-P. 2007. Aspirin resistance and adverse clinical events in patients with coronary artery disease. Am J Med 120: 631-635. doi:10.1016/j.amjmed.2006.10.021

Chimowitz MI, Lynn MJ, Howlett-Smith H, Stern BJ, Hertzberg VS, Frankel MR, Levine SR, Chaturvedi S, Kasner SE, Benesch CG, et al. 2005. Comparison of warfarin and aspirin for symptomatic intracranial arterial stenosis. N Engl J Med 352: 1305-1316. doi:10.1056/NEJMoa043033

Cuisset T, Loosveld M, Morange PE, Quilici J, Moro PJ, Saut N, Gaborit B, Castelli C, Beguin S, Grosdidier C, et al. 2012. CYP2C19* 2 and* 17 alleles have a significant impact on platelet response and bleeding risk in patients treated with prasugrel after acute coronary syndrome. JACC Cardiovasc Interv 5: 1280-1287. doi:10.1016/j.jcin.2012.07.015

Dayoub EJ, Seigerman M, Tuteja S, Kobayashi T, Kolansky DM, Giri J, Groeneveld PW. 2018. Trends in platelet adenosine diphosphate $\mathrm{P} 2 \mathrm{Y}_{12}$ receptor inhibitor use and adherence among antiplatelet-naive patients after percutaneous coronary intervention, 2008-2016. JAMA Intern Med 178: 943-950. doi:10.1001/jamai nternmed.2018.0783

Dewey FE, Murray MF, Overton JD, Habegger L, Leader JB, Fetterolf SN, O’Dushlaine C, Van Hout CV, Staples J, Gonzaga-Jauregui C, et al. 2016. Distribution and clinical impact of functional variants in 50,726 wholeexome sequences from the DiscovEHR study. Science 354: aaf6814. doi:10.1126/science.aaf6814

Diener H-C, Bogousslavsky J, Brass LM, Cimminiello C, Csiba L, Kaste M, Leys D, Matias-Guiu J, Rupprecht HJ. 2004. Aspirin and clopidogrel compared with clopidogrel alone after recent ischaemic stroke or transient ischaemic attack in high-risk patients (MATCH): randomised, double-blind, placebo-controlled trial. Lancet 364: 331-337. doi:10.1016/S0140-6736(04)16721-4

Farid NA, Kurihara A, Wrighton SA. 2010. Metabolism and disposition of the thienopyridine antiplatelet drugs ticlopidine, clopidogrel, and prasugrel in humans. J Clin Pharmacol 50: 126-142. doi:10.1177/ 0091270009343005

Fiore M, Horovitz A, Pons A-C, Leroux L, Casassus F. 2014. First report of a subacute stent thrombosis in a prasugrel resistant patient successfully managed with ticagrelor. Platelets 25: 636-638. doi:10.3109/ 09537104.2013 .852659

Fisch AS, Yerges-Armstrong LM, Backman JD, Wang H, Donnelly P, Ryan KA, Parihar A, Pavlovich MA, Mitchell BD, O'Connell JR, et al. 2015. Genetic variation in the platelet endothelial aggregation receptor 1 gene results in endothelial dysfunction. PLoS One 10: e0138795. doi:10.1371/journal.pone.0138795

Fujiwara T, Ikeda M, Esumi K, Fujita T, Kono M, Tokushige H, Hatoyama T, Maeda T, Asai T, Ogawa T, et al. 2007. Exploratory aspirin resistance trial in healthy Japanese volunteers (J-ART) using platelet aggregation as a measure of thrombogenicity. Pharmacogenomics J 7: 395-403. doi:10.1038/sj.tpj.6500435

Gage BF, Bass AR, Lin H, Woller SC, Stevens SM, Al-Hammadi N, Li J, Rodríguez T, Miller JP, McMillin GA, et al. 2017. Effect of genotype-guided warfarin dosing on clinical events and anticoagulation control among patients undergoing hip or knee arthroplasty: the GIFT randomized clinical trial. JAMA 318: 1115-1124. doi:10.1001/jama.2017.11469

Geisler T, Anders N, Paterok M, Langer H, Stellos K, Lindemann S, Herdeg C, May AE, Gawaz M. 2007. Platelet response to clopidogrel is attenuated in diabetic patients undergoing coronary stent implantation. Diabetes Care 30: 372-374. doi:10.2337/dc06-1625

Gilard M, Arnaud B, Le Gal G, Abgrall J-F, Boschat J. 2006. Influence of omeprazol on the antiplatelet action of clopidogrel associated to aspirin. J Thromb Haemost 4: 2508-2509. doi:10.1111/j.1538-7836.2006 $.02162 . x$

Gilard M, Arnaud B, Cornily J-C, Le Gal G, Lacut K, Le Calvez G, Mansourati J, Mottier D, Abgrall J-F, Boschat J. 2008. Influence of omeprazole on the antiplatelet action of clopidogrel associated with aspirin. J Am Coll Cardiol 51: 256-260. doi:10.1016/j.jacc.2007.06.064

Giorgi MA, Cohen Arazi H, Gonzalez CD, Di Girolamo G. 2011. Beyond efficacy: pharmacokinetic differences between clopidogrel, prasugrel and ticagrelor. Expert Opin Pharmacother 12: 1285-1295. doi:10.1517/ 14656566.2011.550573 
Gong IY, Crown N, Suen CM, Schwarz UI, Dresser GK, Knauer MJ, Sugiyama D, DeGorter MK, Woolsey S, Tirona RG, et al. 2012. Clarifying the importance of CYP2C19 and PON1 in the mechanism of clopidogrel bioactivation and in vivo antiplatelet response. Eur Heart J 33: 2856-2864. doi:10.1093/eurheartj/ehs042

Gum PA, Kottke-Marchant K, Poggio ED, Gurm H, Welsh PA, Brooks L, Sapp SK, Topol EJ. 2001. Profile and prevalence of aspirin resistance in patients with cardiovascular disease. Am J Cardiol 88: 230-235. doi:10 .1016/S0002-9149(01)01631-9

Gum PA, Kottke-Marchant K, Welsh PA, White J, Topol EJ. 2003. A prospective, blinded determination of the natural history of aspirin resistance among stable patients with cardiovascular disease. J Am Coll Cardiol 41: 961-965. doi:10.1016/S0735-1097(02)03014-0

Gurbel PA, Tantry US. 2007. Clopidogrel resistance? Thromb Res 120: 311-321. doi:10.1016/j.thromres.2006 .08 .012

Hankey GJ, Eikelboom JW. 2006. Aspirin resistance. Lancet 367: 606-617. doi:10.1016/S0140-6736(06) 68040-9

Hass WK, Easton JD, Adams HP Jr, Pryse-Phillips W, Molony BA, Anderson S, Kamm B. 1989. A randomized trial comparing ticlopidine hydrochloride with aspirin for the prevention of stroke in high-risk patients. $N$ Engl J Med 321: 501-507. doi:10.1056/NEJM198908243210804

Helgason CM, Tortorice KL, Winkler SR, Penney DW, Schuler JJ, McClelland T, Brace LD. 1993. Aspirin response and failure in cerebral infarction. Stroke 24: 345-350. doi:10.1161/01.STR.24.3.345

Ho PM, Maddox TM, Wang L, Fihn SD, Jesse RL, Peterson ED, Rumsfeld JS. 2009. Risk of adverse outcomes associated with concomitant use of clopidogrel and proton pump inhibitors following acute coronary syndrome. JAMA 301: 937-944. doi:10.1001/jama.2009.261

Huber K, Yasothan U, Hamad B, Kirkpatrick P. 2009. Prasugrel. Nat Rev Drug Discov 8: 449-450. doi:10.1038/ nrd2899

Hulot J-S, Collet J-P, Cayla G, Silvain J, Allanic F, Bellemain-Appaix A, Scott SA, Montalescot G. 2011. CYP2C19 but not PON1 genetic variants influence clopidogrel pharmacokinetics, pharmacodynamics, and clinical efficacy in post-myocardial infarction patients. Circ Cardiovasc Interv 4: 422-428. doi:10 1161/CIRCINTERVENTIONS.111.963025

Hwang S-J, Jeong Y-H, Kim I-S, Koh J-S, Kang M-K, Park Y, Kwak CH, Hwang J-Y. 2011. The cytochrome 2C19* 2 and* 3 alleles attenuate response to clopidogrel similarly in East Asian patients undergoing elective percutaneous coronary intervention. Thromb Res 127: 23-28. doi:10.1016/j.thromres.2010.10.021

Johnson JA, Caudle KE, Gong L, Whirl-Carrillo M, Stein CM, Scott SA, Lee M, Gage BF, Kimmel SE, Perera MA, et al. 2017. Clinical Pharmacogenetics Implementation Consortium (CPIC) guideline for pharmacogenetics-guided warfarin dosing: 2017 update. Clin Pharmacol Ther 102: 397-404. doi:10.1002/cpt.668

Johnston SC, Amarenco P, Albers GW, Denison H, Easton JD, Evans SR, Held P, Jonasson J, Minematsu K, Molina CA, et al. 2016. Ticagrelor versus aspirin in acute stroke or transient ischemic attack. N Engl J Med 375: 35-43. doi:10.1056/NEJMoa1603060

Krasopoulos G, Brister SJ, Beattie WS, Buchanan MR. 2008. Aspirin "resistance" and risk of cardiovascular morbidity: systematic review and meta-analysis. BMJ 336: 195-198. doi:10.1136/bmj.39430.529549.BE

Kupstyte N, Zaliunas R, Tatarunas V, Skipskis V, Zaliaduonyte-Peksiene D, Grabauskyte I, Dovidaitiene D, Bumblauskas K, Gustiene O, Lesauskaite V. 2015. Effect of clinical factors and gene polymorphism of CYP2C19*2,*17 and CYP4F2*3 on early stent thrombosis. Pharmacogenomics 16: 181-189. doi:10 .2217 /pgs. 14.165

Lee JM, Park S, Shin D-J, Choi D, Shim CY, Ko Y-G, Kim J-S, Shin E-S, Chang CW, Lee J-E, et al. 2009. Relation of genetic polymorphisms in the cytochrome P450 gene with clopidogrel resistance after drug-eluting stent implantation in Koreans. Am J Cardiol 104: 46-51. doi:10.1016/j.amjcard.2009.02.045

Lepäntalo A, Mikkelsson J, Reséndiz JC, Viiri L, Backman JT, Kankuri E, Karhunen PJ, Lassila R. 2006. Polymorphisms of COX-1 and GP VI associate with the antiplatelet effect of aspirin in coronary artery disease patients. Thromb Haemost 95: 253-259. doi:10.1160/TH05-07-0516

Levine GN, Bates ER, Bittl JA, Brindis RG, Finn SD, Fleisher LA, Granger CB, Lange RA, Mack MJ, Mauri L, et al. 2016. 2016 ACC/AHA guideline focused update on duration of dual antiplatelet therapy in patients with coronary artery disease: a report of the American College of Cardiology/American Heart Association Task Force on Clinical Practice Guidelines. J Am Coll Cardiol 68: 1082-1115. doi:10.1016/j.jacc.2016.03.513

Lewis JP, Shuldiner AR. 2017. Clopidogrel pharmacogenetics: beyond candidate genes and genome-wide association studies. Clin Pharmacol Ther 101: 323-325. doi:10.1002/cpt.519

Lewis JP, Horenstein RB, Ryan K, O'Connell JR, Gibson Q, Mitchell BD, Tanner K, Chai S, Bliden KP, Tantry US, et al. 2013. The functional G143E variant of carboxylesterase 1 is associated with increased clopidogrel active metabolite levels and greater clopidogrel response. Pharmacogenet Genomics 23: 1. doi:10.1097/ FPC.0b013e32835aa8a2

Li X, Zhang L, Chen X, Qu F, Li J, Ma C, Yang J, Xu B, Wang H, Xu Q, et al. 2013. PON1 Q192R genotype influences clopidogrel responsiveness by relative platelet inhibition instead of on-treatment platelet reactivity. Thromb Res 132: 444-449. doi:10.1016/j.thromres.2013.08.004 
Li M, Hu Y, Wen Z, Li H, Hu X, Zhang Y, Zhang Z, Xiao J, Tang J, Chen X. 2017. Association of PEAR1 rs12041331 polymorphism and pharmacodynamics of ticagrelor in healthy Chinese volunteers. Xenobiotica 47: 1130-1138. doi:10.1080/00498254.2016.1271962

Marcucci R, Paniccia R, Antonucci E, Gori AM, Fedi S, Giglioli C, Valente S, Prisco D, Abbate R, Gensini GF. 2006. Usefulness of aspirin resistance after percutaneous coronary intervention for acute myocardial infarction in predicting one-year major adverse coronary events. Am J Cardiol 98: 1156-1159. doi:10.1016/j .amjcard.2006.05.041

Marcucci R, Giusti B, Paniccia R, Gori AM, Saracini C, Valente S, Giglioli C, Parodi G, Antoniucci D, Gensini GF, et al. 2012. High on-treatment platelet reactivity by ADP and increased risk of MACE in good clopidogrel metabolizers. Platelets 23: 586-593. doi:10.3109/09537104.2012.658106

Markus HS, Droste DW, Kaps M, Larrue V, Lees KR, Siebler M, Ringelstein EB. 2005. Dual antiplatelet therapy with clopidogrel and aspirin in symptomatic carotid stenosis evaluated using Doppler embolic signal detection. Circulation 111: 2233-2240. doi:10.1161/01.CIR.0000163561.90680.1C

Matetzky S, Shenkman B, Guetta V, Shechter M, Beinart R, Goldenberg I, Novikov I, Pres H, Savion N, Varon D, et al. 2004. Clopidogrel resistance is associated with increased risk of recurrent atherothrombotic events in patients with acute myocardial infarction. Circulation 109: 3171-3175. doi:10.1161/01.CIR.0000130846 .46168 .03

Matsubara Y, Murata M, Watanabe G, Ikeda Y. 2008. Enhancing effect of the 145Met-allele of GPIb a on platelet sensitivity to aspirin under high-shear conditions. Thromb Res 123: 331-335. doi:10.1016/j.thromres .2008.02.008

McDonough CW, McClure LA, Mitchell BD, Gong Y, Horenstein RB, Lewis JP, Field TS, Talbert RL, Benavente OR, Johnson JA, et al. 2015. CYP2C19 metabolizer status and clopidogrel efficacy in the Secondary Prevention of Small Subcortical Strokes (SPS3) study. J Am Heart Assoc 4: e001652. doi:10.1161/JAHA .114 .001652

Mega JL, Close SL, Wiviott SD, Shen L, Hockett RD, Brandt JT, Walker JR, Antman EM, Macias WL, Braunwald $\mathrm{E}$, et al. 2009. Cytochrome P450 genetic polymorphisms and the response to prasugrel. Circulation 119: 2553-2560. doi:10.1161/CIRCULATIONAHA.109.851949

Mega JL, Close SL, Wiviott SD, Shen L, Walker JR, Simon T, Antman EM, Braunwald E, Sabatine MS. 2010 Genetic variants in ABCB1 and CYP2C19 and cardiovascular outcomes after treatment with clopidogrel and prasugrel in the TRITON-TIMI 38 trial: a pharmacogenetic analysis. Lancet 376: 1312-1319. doi:10 .1016/S0140-6736(10)61273-1

Mohr J, Thompson J, Lazar RM, Levin B, Sacco R, Furie K, Kistler J, Albers G, Pettigrew L, Adams H Jr, et al. 2001. A comparison of warfarin and aspirin for the prevention of recurrent ischemic stroke. N Engl J Med 345: 1444-1451. doi:10.1056/NEJMoa011258

Montalescot G, Wiviott SD, Braunwald E, Murphy SA, Gibson CM, McCabe CH, Antman EM, TRITON-TIMI 38 investigators. 2009. Prasugrel compared with clopidogrel in patients undergoing percutaneous coronary intervention for ST-elevation myocardial infarction (TRITON-TIMI 38): double-blind, randomised controlled trial. Lancet 373: 723-731. doi:10.1016/S0140-6736(09)60441-4

Park SH, Kim W, Park CS, Kang WY, Hwang SH, Kim W. 2009. A comparison of clopidogrel responsiveness in patients with versus without chronic renal failure. Am J Cardiol 104: 1292-1295. doi:10.1016/j.amjcard 2009.06.049

Price MJ, Murray SS, Angiolillo DJ, Lillie E, Smith EN, Tisch RL, Schork NJ, Teirstein PS, Topol EJ, GIFT Investigators. 2012. Influence of genetic polymorphisms on the effect of high-and standard-dose clopidogrel after percutaneous coronary intervention: the GIFT (Genotype Information and Functional Testing) study. J Am Coll Cardiol 59: 1928-1937. doi:10.1016/j.jacc.2011.11.068

Rideg O, Komócsi A, Magyarlaki T, Tőkés-Füzesi M, Miseta A, Kovács GL, Aradi D. 2011. Impact of genetic variants on post-clopidogrel platelet reactivity in patients after elective percutaneous coronary intervention. Pharmacogenomics 12: 1269-1280. doi:10.2217/pgs.11.73

Roberts JD, Wells GA, Le May MR, Labinaz M, Glover C, Froeschl M, Dick A, Marquis J-F, O’Brien E, Goncalves $\mathrm{S}$, et al. 2012. Point-of-care genetic testing for personalisation of antiplatelet treatment (RAPID GENE): a prospective, randomised, proof-of-concept trial. Lancet 379: 1705-1711. doi:10.1016/S0140-6736(12) 60161-5

Schomig A. 2009. Ticagrelor-is there need for a new player in the antiplatelet therapy field? N Engl J Med 361: 1108. doi:10.1056/NEJMe0906549

Scott SA, Sangkuhl K, Stein C, Hulot JS, Mega J, Roden D, Klein T, Sabatine M, Johnson J, Shuldiner A. 2013. Clinical pharmacogenetics implementation consortium guidelines for CYP2C19 genotype and clopidogrel therapy: 2013 update. Clin Pharmacol Ther 94: 317-323. doi:10.1038/clpt.2013.105

Scott SA, Collet JP, Baber U, Yang Y, Peter I, Linderman M, Sload J, Qiao W, Kini AS, Sharma SK, et al. 2016. Exome sequencing of extreme clopidogrel response phenotypes identifies B4GALT2 as a determinant of on-treatment platelet reactivity. Clin Pharmacol Ther 100: 287-294. doi:10.1002/cpt.401 
Simon T, Verstuyft C, Mary-Krause M, Quteineh L, Drouet E, Méneveau N, Steg PG, Ferrières J, Danchin N, Becquemont L. 2009. Genetic determinants of response to clopidogrel and cardiovascular events. N Engl J Med 360: 363-375. doi:10.1056/NEJMoa0808227

Sorich MJ, Rowland A, McKinnon RA, Wiese MD. 2014. CYP2C19 genotype has a greater effect on adverse cardiovascular outcomes following percutaneous coronary intervention and in Asian populations treated with clopidogrel. Circ Cardiovasc Genet 7: 895-902. doi:10.1161/CIRCGENETICS.114.000669

Sun B, Li J, Dong M, Yang L, Wu C, Zhu L, Cong Y. 2015. Diversity of platelet function and genetic polymorphism in clopidogrel-treated Chinese patients. Genet Mol Res 14: 1434-1442. doi:10.4238/2015. February .13 .22

Tarkiainen E, Holmberg M, Tornio A, Neuvonen M, Neuvonen P, Backman J, Niemi M. 2015. Carboxylesterase 1 c. $428 \mathrm{G}>\mathrm{A}$ single nucleotide variation increases the antiplatelet effects of clopidogrel by reducing its hydrolysis in humans. Clin Pharmacol Ther 97: 650-658. doi:10.1002/cpt.101

Teng R, Oliver S, Hayes MA, Butler K. 2010. Absorption, distribution, metabolism, and excretion of ticagrelor in healthy subjects. Drug Metab Dispos 38: 1514-1521. doi:10.1124/dmd.110.032250

Tiroch KA, Sibbing D, Koch W, Roosen-Runge T, Mehilli J, Schömig A, Kastrati A. 2010. Protective effect of the CYP2C19* 17 polymorphism with increased activation of clopidogrel on cardiovascular events. Am Heart J 160: 506-512. doi:10.1016/j.ahj.2010.06.039

Vane JR. 1971. Inhibition of prostaglandin synthesis as a mechanism of action for aspirin-like drugs. Nature 231: 232-235. doi:10.1038/newbio231232a0

Varenhorst C, James S, Erlinge D, Brandt JT, Braun OÖ, Man M, Siegbahn A, Walker J, Wallentin L, Winters KJ, et al. 2009. Genetic variation of CYP2C19 affects both pharmacokinetic and pharmacodynamic responses to clopidogrel but not prasugrel in aspirin-treated patients with coronary artery disease. Eur Heart J 30: 1744-1752. doi:10.1093/eurheartj/ehp157

Varenhorst C, Eriksson N, Johansson Å, Barratt BJ, Hagström E, Åkerblom A, Syvänen A-C, Becker RC, James SK, Katus HA, et al. 2015. Effect of genetic variations on ticagrelor plasma levels and clinical outcomes. Eur Heart J 36: 1901-1912. doi:10.1093/eurheartj/ehv116

Verschuren JJ, Boden H, Wessels JA, Van der Hoeven BL, Trompet S, Heijmans BT, Putter H, Guchelaar H-J, Schalij MJ, Jukema JW. 2013. Value of platelet pharmacogenetics in common clinical practice of patients with ST-segment elevation myocardial infarction. Int J Cardiol 167: 2882-2888. doi:10.1016/j.ijcard.2012 .07 .020

Wallentin L, James S, Storey RF, Armstrong M, Barratt BJ, Horrow J, Husted S, Katus H, Steg PG, Shah SH, et al. 2010. Effect of CYP2C19 and ABCB1 single nucleotide polymorphisms on outcomes of treatment with ticagrelor versus clopidogrel for acute coronary syndromes: a genetic substudy of the PLATO trial. Lancet 376: 1320-1328. doi:10.1016/S0140-6736(10)61274-3

Wang TH, Bhatt DL, Topol EJ. 2005. Aspirin and clopidogrel resistance: an emerging clinical entity. Eur Heart J 27: 647-654. doi:10.1093/eurheartj/ehi684

Whirl-Carrillo M, McDonagh E, Hebert J, Gong L, Sangkuhl K, Thorn C, Altman R, Klein TE. 2012. Pharmacogenomics knowledge for personalized medicine. Clin Pharmacol Ther 92: 414-417. doi:10 $.1038 / \mathrm{clpt} .2012 .96$

Wiviott SD, Braunwald E, McCabe CH, Montalescot G, Ruzyllo W, Gottlieb S, Neumann F-J, Ardissino D, De Servi S, Murphy SA, et al. 2007. Prasugrel versus clopidogrel in patients with acute coronary syndromes. $N$ Engl J Med 357: 2001-2015. doi:10.1056/NEJMoa0706482

Wu H, Qian J, Xu J, Sun A, Sun W, Wang Q, Ge J. 2012. Effects of CYP2C19 variant alleles on postclopidogrel platelet reactivity and clinical outcomes in an actual clinical setting in China. Pharmacogenet Genomics 22: 887-890. doi:10.1097/FPC.0b013e328359253a

Xiang Q, Cui Y, Zhao X, Zhao N. 2013. Identification of PEAR1 SNPs and their influences on the variation in prasugrel pharmacodynamics. Pharmacogenomics 14: 1179-1189. doi:10.2217/pgs.13.108 


\section{COLD SPRING HARBOR Molecular Case Studies}

\section{Pharmacogenomic considerations for antiplatelet agents: the era of precision medicine in stroke prevention and neurointerventional practice}

Phillip A. Bonney, Benjamin Yim, Waleed Brinjikji, et al.

Cold Spring Harb Mol Case Stud 2019, 5: a003731

Access the most recent version at doi: $10.1101 / \mathrm{mcs} . a 003731$

References This article cites 77 articles, 18 of which can be accessed free at: http://molecularcasestudies.cshlp.org/content/5/2/a003731.full.html\#ref-list-1

License This article is distributed under the terms of the Creative Commons Attribution-NonCommercial License, which permits reuse and redistribution, except for commercial purposes, provided that the original author and source are credited.

Email Alerting Receive free email alerts when new articles cite this article - sign up in the box at the Service top right corner of the article or click here. 